\title{
KEPRIBADIAN DAN MOTIVASI KERJA MEMPENGARUHI KOMITMEN NORMATIF
}

\author{
Hegar Harini ${ }^{1}$, Adisel $^{2}$ \\ STKIP Kusumanegara ${ }^{1}$, IAIN Bengkulu ${ }^{2}$ \\ hegar@stkipkusumanegara.ac.id ${ }^{1}$
}

\begin{abstract}
ABSTRAK
Tujuan penelitian ini adalah untuk mengetahui kepribadian dan motivasi kerja mempengaruhi komitmen normatif kepala sekolah. Penelitian ini menggunakan metode survey yang melibatkan 90 orang kepala sekolah dari sekolah menengah atas negeri di DKI Jakarta. Data yang didapat dianalisis dengan pendekatan path analysis. Simpulan, kepribadian dan motivasi kerja berpengaruh langsung positif terhadap komitmen normatif kepala sekolah. Ini menandakan bahwa semakin baik kepribadian dan semakin tinggi motivasi kerja, maka komitmen normatif kepala sekolah akan meningkat.
\end{abstract}

Kata Kunci: Kepribadian, Motivasi, Komitmen Normatif.

\section{ABSTRACT}

The purpose of this study was to determine the personality and work motivation to influence the normative commitment of the principal. This study used a survey method involving 90 school principals from public high schools in DKI Jakarta. The data obtained were analyzed using the path analysis approach. In conclusion, personality and work motivation have a positive direct effect on normative commitment of school principals. This indicates that the better the personality and the higher the work motivation, the higher the normative commitment of the school principal.

Keywords: Personality, Motivation, Normative Commitment.

\section{PENDAHULUAN}

Sekolah sebagai salah satu lembaga pengembangan keterampilan serta kecakapan hidup harus mampu meningkatkan kualitas sumber daya manusia Indonesia guna menjawab tantangan dalam persaingan global. Oleh karena itu, dituntut seorang kepala sekolah yang memiliki komitmen tinggi, dan diwujudkan dalam bentuk program pendidikan berkualitas dalam upaya peningkatan kualitas manusia Indonesia.

Kondisi real kepala sekolah saat ini di lapangan banyak yang menjadi terduga melakukan pelanggaran dalam bidang manajemen. Seperti kutipan dari pernyataan Gubernur DKI Jakarta periode 2012-2017, Basuki Tjahaja Purnama, mengatakan bahwa sembilan kepala sekolah diduga terlibat pungutan liar yang akhirnya dipecat dari jabatannya karena telah mencoreng dunia pendidikan yang 
sudah mulai berbenah diri. Dalam kasus tersebut, komitmen organisasi yang dimiliki kepala sekolah masih tergolong sangat rendah terhadap profesinya. Adapun salah satu komitmen organisasi yang penting dimiliki oleh seorang kepala sekolah adalah komitmen normatif. Komitmen normatif adalah hal yang penting karena merefleksikan bagaimana seseorang bertahan dalam sebuha organisasi (Meyer, et.al, 2002). Sementara Kondalkar (2007) menyatakan bahwa komitmen normatif berkaitan dengan keyakinan yang pasti dan penerimaan nilai dan tujuan organisasi. Kepala sekolah yang memiliki komitmen normatif akan mengacu pada standar perilaku atau norma sosial dalam proses kepemimpinannya.

Upaya meningkatkan komitmen normatif kepala sekolah seyogyanya ditunjang dengan kepribadian dan motivasi kerja. Kepala sekolah yang memiliki motivasi kerja yang tinggi akan membantu meningkatkan komitmen normatif untuk kemajuan sekolah. Adapun komitmen normatif kepala sekolah yang cenderung rendah maka akan berhubungan dengan kepribadian yang dimiliki kepala sekolah yang bersangkutan. Elleman et al. (2018) menyatakan bahwa kepribadian yang berkaitan erat dengan komitmen organisasi bisa didasarkan pada kehati-hatian, kesepakatan, kestabilan emosi, keterbukaan dan kepatuhan.

Penelitian tentang pengaruh kepribadian dan motivasi kerja sudah banyak dilakukan oleh sejumlah peneliti. Tella et al. (2007) menemukan bahwa keberlangsungan sebuah perusahaan tidak hanya ditentukan oleh produktivitas, namun juga didukung oleh motivasi pegawai yang kuat. Bidang kesehatan, Selma (2011) melakukan survey kepada tenaga medis dan menemukan bahwa motivasi intinsik berpengaruh positif terhadap komitmen normatif. Oladiipo et al. (2019) menemukan hasil serupa, bahwa faktor motivasi merupakan hal yang memberikan efek signifikan terhadap komitmen terdap pekerjaan. Sektor pendidikan nonformal, Rahmawati, et.al, (2015) menemukan bahwa komitmen organisasi anggota pramuka sangat ditentukan oleh motivasi mereka. Sementara Abdullah et. al. (2013), setelah melakukan penelitian di sektor perbankan, melaporkan bahwa kepribadian mempengaruhi komitmen organisasi para pegawai terutama dalam aspek kehati-hatian, kestabilan emosi dan kesepakatan. Penelitian pada staf universitas pun pernah dilakukan oleh Khiavi et al. (2016), kepribadian berpengaruh positif terhadap komitmen normatif di mana aspek kehati-hatian menjadi prediktor utamanya.

Leephaijaroen (2016) melakukan penelitian sejenis pada sejumlah staf universitas, dan melaporkan bahwa kepribadian memberikan pengaruh berarti terhadap komitmen normatif dengan prediktor terkuatnya yaitu kesepakatan dan kehati-hatian. Penelitian dengan sampel serupa juga pernah dilakukan oleh Farrukh et al. (2017), di mana mereka menemukan bahwa komitmen organisasi memang dipengaruhi oleh kepribadian pegawai, dan mereka menemukan bahwa kesepakatan memberikan pengaruh yang paling signifikan.

Hasil penelitian terdahulu dilakukan di sektor usaha dan pendidikan tinggi. Sementara penelitian di bidang pendidikan menengah khususnya yang 
menjadikan kepala sekolah sebagai sampel masih jarang ditemukan. Selain itu, penelitian-penelitian di atas pun umumnya tidak mengintegrasikan variabel motivasi dan kepribadian untuk dihubungkan dengan komitmen normatif secara keseluruhan. Namun, penelitian ini akan menggali bagaimana komitmen normatif kepala sekolah sebagai salah satu pemangku kebijakan di sekolah. Tak kalah pentingnya, penelitian ini juga mengintegrasikan bagaimana kepribadian dan motivasi berpengaruh terhadap komitmen normatif kepala sekolah.

\section{METODE PENELITIAN}

Penelitian ini menggunakan metode survei dengan pendekatan path analysis. Cara untuk pengumpulan data yang diperlukan dalam penelitian ini dilakukan melalui kuesioner, mengkaji keterkaitan antar variabel penelitian serta mengukur variable yang satu dengan yang lain. Unit analisisnya adalah Kepala Sekolah SMA Negeri di DKI Jakarta, Indonesia. Sampel diambil dengan menggunakan teknik simple random sampling dengan berpedoman pada rumus teknik sampel dari Slovin, dengan jumlah sampel adalah $90(n=90)$. Pengujian hipotesa penelitian ini dengan model konstelasi antar variabel, terdiri dari 3 variabel yaitu; variabel eksogen Kepribadian $\left(\mathrm{X}_{1}\right)$, Motivasi $\operatorname{Kerja}\left(\mathrm{X}_{2}\right)$, dan variabel endogen; Komitmen Normatif (Y). Adapun konstelasi model permasalahan penelitian yang menunjukkan model hubungan antara variabel eksogenus (X) dengan variabel endogenus (Y) disajikan pada gambar 1.

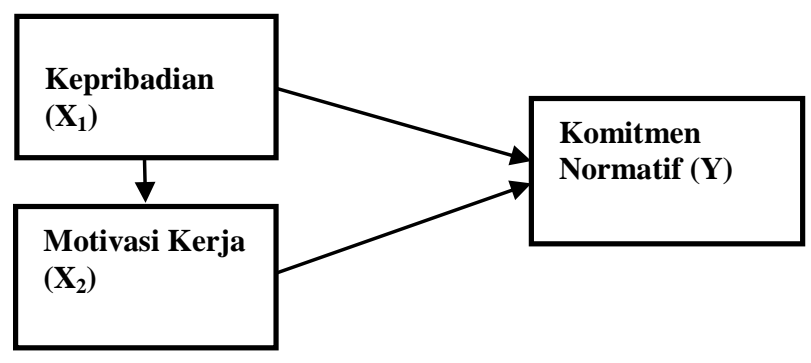

Gambar 1. Gambar Konstelasi Model Permasalahan Penelitian

Keterangan:

$\begin{array}{ll}\mathrm{Y} & : \text { Komitmen Normatif } \\ \mathrm{X}_{1} & : \text { Kepribadian } \\ \mathrm{X}_{2} & : \text { Motivasi Kerja }\end{array}$

\section{HASIL PENELITIAN}

Dalam penggunaan teknik path analysis terdapat uji prasyarat analisis yang harus dipenuhi, dalam penelitian ini pengujian persyaratan analisis yang digunakan adalah normalitas, uji linearitas, dan uji signifikansi regresi. Berikut disajikan masing-masing pengujian persyaratan analisis. 
Tabel 1 Rangkuman Hasil Uji Normalitas

\begin{tabular}{|c|c|c|c|c|c|c|}
\hline \multirow{2}{*}{ No } & \multirow{2}{*}{ Galat Taksiran Regresi } & \multirow{2}{*}{$\mathrm{n}$} & \multirow{2}{*}{ L-hitung } & \multicolumn{2}{|l|}{$\mathrm{L}-$ tabel } & \multirow{2}{*}{ - Keterangan } \\
\hline & & & & $\alpha=5 \%$ & $\alpha=1 \%$ & \\
\hline 1. & $\mathrm{Y}$ atas $\mathrm{X}_{1}$ & 90 & 0,071 & 0,093 & 0,109 & Normal \\
\hline 2. & $\mathrm{Y}$ atas $\mathrm{X}_{2}$ & 90 & 0,063 & 0,093 & 0,109 & Normal \\
\hline 3. & $\mathrm{X}_{2}$ atas $\mathrm{X}_{1}$ & 90 & 0,052 & 0,093 & 0,109 & Normal \\
\hline
\end{tabular}

Berdasarkan hasil perhitungan uji normalitas tersebut di atas diketahui $\mathrm{L}_{\text {count }} \leq \mathrm{L}_{\text {table, }}$, sehingga dapat disimpulkan bahwa distribusi galat taksiran antar variabel berasal dari populasi yang memiliki distribusi normal.

Tabel 2 Rangkuman Hasil Uji Signifikansi dan Linieritas Regresi

\begin{tabular}{|c|c|c|c|c|c|c|}
\hline \multirow{3}{*}{ Reg } & \multirow{3}{*}{ Persamaan } & \multicolumn{2}{|c|}{ Uji Regresi } & \multicolumn{2}{|c|}{ Linearity Test } & \multirow{3}{*}{ Kesimpulan } \\
\hline & & \multirow[b]{2}{*}{$\mathrm{F}_{\text {hitung }}$} & \multirow{2}{*}{$\begin{array}{l}F_{\text {table }} \\
\alpha=0,01\end{array}$} & \multirow[b]{2}{*}{$\mathrm{F}_{\text {hitung }}$} & \multirow{2}{*}{$\begin{array}{l}F_{\text {table }} \\
\alpha \\
0,05\end{array}$} & \\
\hline & & & & & & \\
\hline $\begin{array}{l}\mathrm{Y} \text { atas } \\
\mathrm{X}_{1}\end{array}$ & $\begin{array}{lr}\widehat{\mathbf{Y}} & =99,48 \\
+ & 0,424 \\
\mathrm{X} 1 & \\
\end{array}$ & 31,26 & $6,93 * *$ & 0,767 & $1,64 \mathrm{~ns}$ & $\begin{array}{l}\text { Regresi sangat signifikan/ } \\
\text { Regresi linear }\end{array}$ \\
\hline $\begin{array}{l}\mathrm{Y} \text { atas } \\
\mathrm{X}_{2}\end{array}$ & $\begin{array}{lr}\widehat{\mathbf{x}} & =92,48 \\
+ & 0,563 \\
\mathrm{X} 3 & \\
\end{array}$ & 29,88 & $6,93 * *$ & 1,183 & $1,64 \mathrm{~ns}$ & $\begin{array}{l}\text { Regresi sangat signifikan/ } \\
\text { Regresi linear }\end{array}$ \\
\hline $\begin{array}{l}\mathrm{X}_{2} \text { atas } \\
\mathrm{X}_{1}\end{array}$ & $\begin{array}{l}\widehat{\mathrm{X}}_{\mathrm{z}}=78,05 \\
+ \\
\mathrm{X} 1\end{array}$ & 32,68 & $6,93 * *$ & 0,721 & $1,64 \mathrm{~ns}$ & $\begin{array}{l}\text { Regresi sangat signifikan/ } \\
\text { Regresi linear }\end{array}$ \\
\hline
\end{tabular}

Berdasarkan tabel di atas, diketahui bahwa untuk uji regresi signifikansi diperoleh bahwa $\mathrm{F}_{\text {-hitung }} \geq \mathrm{F}_{\text {-tabel, }}$, adapun uji regresi linear adalah $\mathrm{F}_{\text {-hitung }}<\mathrm{F}_{\text {-tabel, }}$, sehingga dapat disimpulkan bahwa Regresi sangat signifikan dan linear. Koefisien jalur dalam model hipotetik penelitian adalah py1, py2, p21, dalam menentukan besaran jalur pada sebuah model hipotetik penelitian di peroleh dengan menentukan besaran nilai korelasi yang kemudian dilanjutkan dengan mencari nilai koefisein jalur, dan kemudian dilanjutkan uji signifikansi koefisien jalur. Berdasarkan hasil perhitungan diperoleh matrik korelasi antar variable disajikan pada table 3 sebagai berikut.

Table 3.Matriks Korelasi Antar Variabel

\begin{tabular}{cccc}
\hline$r$ & $\mathrm{X}_{1}$ & $\mathrm{X}_{2}$ & $\mathrm{Y}$ \\
\hline $\mathrm{X}_{1}$ & 1,000 & 0,520 & 0,512 \\
\hline $\mathrm{X}_{2}$ & 0,520 & 1,000 & 0,503 \\
\hline $\mathrm{Y}$ & 0,512 & 0,503 & 1,000 \\
\hline
\end{tabular}


Adapun besaran pengaruh langsung dan uji signifikansi setiap jalur (Path Analysis) dirangkum pada table berikut.

Table 4 Rangkuman Hasil Uji Signifikansi Jalur

\begin{tabular}{|c|c|c|c|c|c|c|}
\hline \multirow{2}{*}{ No. } & \multirow{2}{*}{$\begin{array}{l}\text { Pengaruh } \\
\text { Langsung }\end{array}$} & \multirow{2}{*}{$\begin{array}{l}\text { Coefficient } \\
\text { Jalur }\end{array}$} & \multirow{2}{*}{$\mathrm{dk}$} & \multirow{2}{*}{$\mathrm{T}_{\text {hitung }}$} & \multicolumn{2}{|l|}{$t_{\text {tabel }}$} \\
\hline & & & & & $\alpha=0,05$ & $\alpha=0,01$ \\
\hline 1. & $\mathrm{X}_{1}$ terhadap $\mathrm{Y}$ & 0,279 & 86 & 2,70 & 1,99 & 2,63 \\
\hline 2. & $\mathrm{X}_{2}$ terhadap $\mathrm{Y}$ & 0,242 & 86 & 2,27 & 1,99 & 2,63 \\
\hline 3. & $\mathrm{X}_{1}$ terhadap $\mathrm{X}_{2}$ & 0,366 & 87 & 3,78 & 1,99 & 2,63 \\
\hline
\end{tabular}

Secara struktural diagram keseluruhan jalur setiap struktur dapat dilihat pada Gambar 2 berikut:

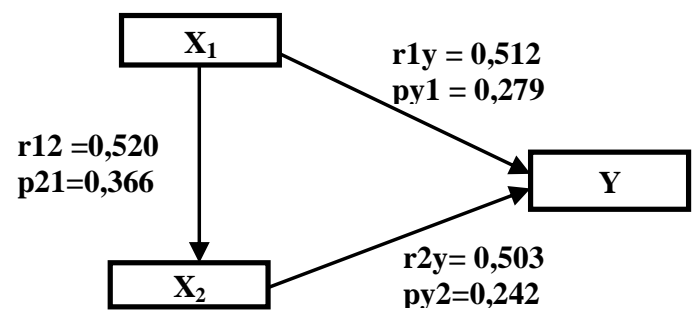

Gambar 2. Diagram Jalur Kausal Pengaruh $\mathrm{X}_{1}$ dan $\mathrm{X}_{2}$ terhadap $\mathrm{Y}$.

\section{Terdapat pengaruh langsung positif Kepribadian $\left(X_{1}\right)$ terhadap Komitmen Normative (Y).}

Hipotesis statistik yang diuji adalah berpengaruh langsung positif Kepribadian (X1) terhadap Komitmen Normatif (Y).

Hipotesis Statistik:

$\mathrm{H} 0: \beta y 1 \leq 0$

$\mathrm{H} 1: \beta \mathrm{y} 1>0$

Berdasarkan hasil analisis jalur pengaruh Kepribadian $\left(\mathrm{X}_{1}\right)$ terhadap Komitmen Normatif ( $\mathrm{Y}$ ) diperoleh koefisien jalur $\rho y 1$ sebesar 0,279 dengan $\mathrm{t}_{\text {hitung }}$ $=2,70$, sedangkan nilai $t_{\text {tabel }}=1,99(\alpha=0,05 ; \mathrm{dk}=86)$. Oleh karena $t_{\text {hitung }}>t_{\text {tabel }}$, maka $\mathrm{H}_{0}$ ditolak, $\mathrm{H}_{1}$ diterima. Dengan demikian dapat disimpulkan bahwa Kepribadian berpengaruh langsung positif terhadap Komitmen Normatif.

Terdapat pengaruh langsung positif Motivasi Kerja $\left(\mathbf{X}_{2}\right)$ terhadap Komitmen Normative (Y).

Hipotesis statistik yang diuji adalah berpengaruh langsung positif Motivasi Kerja $\left(\mathrm{X}_{2}\right)$ terhadap Komitmen Normatif $(\mathrm{Y})$. 
Hipotesis Statistik:

$\mathrm{H} 0: \beta \mathrm{y} 2 \leq 0$

$\mathrm{H} 1: \beta \mathrm{y} 2>0$

Berdasarkan hasil analisis jalur pengaruh Motivasi Kerja $\left(\mathrm{X}_{2}\right)$ terhadap Komitmen Normatif (Y) diperoleh koefisien jalur $\rho y 1$ sebesar 0,242 dengan $t_{\text {hitung }}$ $=2,27$, sedangkan nilai $t_{\text {tabel }}=1,99(\alpha=0,05 ; \mathrm{dk}=86)$. Oleh karena $t_{\text {hitung }}>t_{\text {tabel }}$, maka $\mathrm{H}_{0}$ ditolak, $\mathrm{H}_{1}$ diterima. Dengan demikian dapat disimpulkan bahwa Motivasi Kerja berpengaruh langsung positif terhadap Komitmen Normatif.

Terdapat pengaruh langsung positif Kepribadian $\left(\mathbf{X}_{1}\right)$ terhadap Motivasi $\operatorname{Kerja}\left(\mathbf{X}_{2}\right)$.

Hipotesis statistik yang diuji adalah berpengaruh langsung positif Kepribadian $\left(\mathrm{X}_{1}\right)$ terhadap Motivasi Kerja $\left(\mathrm{X}_{2}\right)$.

Hipotesis Statistik:

$\mathrm{H} 0: \beta \mathrm{p} 21 \leq 0$

$\mathrm{H} 1: \beta \mathrm{p} 21>0$

Berdasarkan hasil analisis jalur pengaruh Kepribadian $\left(\mathrm{X}_{1}\right)$ terhadap Motivasi Kerja $\left(\mathrm{X}_{2}\right)$ diperoleh koefisien jalur $\rho 21$ sebesar 0,366 dengan $\mathrm{t}_{\text {hitung }}=$ 3,78 , sedangkan nilai $t_{\text {tabel }}=1,99(\alpha=0,05 ; d k=87)$. Oleh karena $t_{\text {hitung }}>t_{\text {tabel }}$, maka $\mathrm{H}_{0}$ ditolak, $\mathrm{H}_{1}$ diterima. Dengan demikian dapat disimpulkan bahwa Kepribadian berpengaruh langsung positif terhadap Motivasi Kerja.

\section{PEMBAHAAN}

Berdasarkan hasil analisis dan pengujian hipotesis menunjukkan bahwa ketiga hipotesis yang diajukan dalam penelitian ini secara umum terbukti setiap jalur berpengaruh langsung positif. Hasil penelitian ini sejalan dengan hasil penelitian sebelumnya yang dilakukan oleh Supramono, et.al (2015) dan Novian, et.al (2019) yang menyatakan bahwa motivasi dan kepribadian memberikan pengaruh yang besar dan signifikan terhadap komitmen organisasi dan komitmen normatif. Secara rinci, pembahasan analisis dan pengujian hipotesis penelitian diuraikan sebagai berikut.

\section{Kepribadian Berpengaruh Langsung Positif terhadap Komitmen Normatif}

Hasil pengujian hipotesis diperoleh nillai koefisien jalur (py1) sebesar 0,279 yang artinya tolak $\mathrm{H}_{0}$ terima $\mathrm{H}_{1}$ hal ini membuktikan bahwa terdapat pengaruh langsung positif kepribadian terhadap komitmen normatif kepala sekolah. Hasil dari analisis jalur antara variabel kepribadian dengan variabel komitmen normatif memberikan pengertian bahwa pengaruh kepribadian terhadap komitmen normatif adalah positif, yang dapat diartikan bahwa semakin baik kepribadian maka komitmen normatif kepala sekolah akan meningkat, begitu juga sebaliknya semakin rendah kepribadian akan di ikuti rendahnya komitmen normatif kepala sekolah. 
Berdasarkan hasil analisis data di atas, dan perhitungan statistik yang telah dijelaskan, hal ini juga didukung dari hasil penelitian yang menyatakan adanya pengaruh langsung kepribadian terhadap komitmen normatif. Di antaranya yaitu Kumar (2012) yang menjelaskan bahwa "Kepala sekolah memiliki nilai keterbukaan, keadilan, komitmen terhadap organisasi, dan integritas moral merupakan yang paling efektif dan normatif dalam memprediksi komitmen organisasi bentuk nilai tertinggi dari komitmen organisasi dan kepribadian". Nilai kepribadian signifikan dalam menentukan komitmen organizational, dan kepala sekolah harus memiliki pribadi dengan nilai keterbukaan, keadilan, logika, dan integritas moral yang tinggi dan mempromosikan kepribadian dalam organisasinya, maka akanmenjadi yang lebih efektif dan berkomitmen secara normatif.

Adapun Nelson \& Cooper (2007) menyatakan bahwa, komitmen organisasi menyangkut keingintahuan. Pengawasan menyangkut kemampuan untuk mempengaruhi dan mengambil pengaruh tanggung jawab. Selanjutnya Colquitt et al., (2009) mengemukakan, bahwa kestabilan emosi membuat karyawan lebih berkomitmen terhadap organisasi mereka. begitu pun dengan hasil penelitian ini yang mengimplikasikan bahwa bahwa kepala sekolah dengan kepribadian yang baik cenderung lebih berkomitmen pada organisasinya.

Temuan dalam penelitian ini mendukung hasil penelitian sebelumnya yang dikemukakan oleh Leephaijaroen (2016) yang menemukan bahwa kelima jenis, the findings above revealed that the big-five personality traits and organizational commitment have positive conscientious personality, and normative commitment. Ciri-ciri kepribadian dan komitmen organisasi, kepala sekolah harus memiliki kepribadian bersikap keterbukaan, dan komitmen normatif.

\section{Motivasi Kerja Berpengaruh Langsung Positif terhadap Komitmen Normatif}

Hasil pengujian hipotesis diperoleh nillai koefisien jalur (py2) sebesar 0,242 yang artinya tolak $\mathrm{H}_{0}$ terima $\mathrm{H}_{1}$ hal ini membuktikan bahwa terdapat pengaruh langsung positif motivasi kerja terhadap komitmen normatif kepala sekolah. Hasil analisis jalur antara variabel motivasi kerja dengan variabel komitmen normatif memberikan pengertian bahwa pengaruh motivasi kerja terhadap komitmen normatif adalah positif, yang dapat diartikan tingkat motivasi kerja yang tinggi akan meningkatkan komitmen normatifkepala sekolah, begitu juga sebaliknya semakin rendah tingkat motivasi kerja akan di ikuti rendahnya komitmen normatif kepala sekolah.

Hasil penelitian ini senada dengan penelitian Huang (2015) yang mengungkapkan bahwa motivasi intrinsik berhubungan positif dengan komitmen normatif. Hipotesis ini didukung oleh analisis SEM (koefisien jalur $=0,436$, $\mathrm{p} \leq 0,01$ ). Hasilnya menunjukkan bahwa individu dengan tingkat motivasi intrinsik yang tinggi lebih cenderung memiliki komitmen normatif yang tinggi. Ukuran pengaruh motivasi intrinsik pada komitmen normatif adalah 0,192 , yang berarti 
bahwa 19,2 persen dari varian komitmen normatif ditegaskan oleh motivasi intrinsik. Sebagai tambahan, penelitian Sinani (2016) membuktikan bahwa faktorfaktor dalam motivasi memberikan efek yang kuat terhadap komitmen organisasi para pendidik di sekolah.

Adapun Gibson et al. (2009) berpendapat, bahwa "bukti penelitian menunjukkan bahwa tidak adanya komitmen dapat mengurangi efektivitas organisasi. Penghargaan intrinsik penting untuk mengembangkan komitmen organisasional. Organisasi sekolah mampu memenuhi kebutuhan dengan memberikan kesempatan yang menantang, memberikan umpan balik, mendorong partisipasi kepala sekolah dan dengan mengenali prestasi saat terjadi memiliki dampak signifikan terhadap komitmen.

Selanjutnya Huang (2015) berpendapat, bahwa "normative commitment refers to a feeling of obligation to continue employment. Previous work on the relation between intrinsic motivation and normative commitment is very limited. As mentioned, the social value or obligation that keeps an individual working in a certain organization is not a personal need or goal, but the personal needs of all social members may shape social values". Komitmen normatif mengacu pada perasaan kewajiban untuk pekerjaan. Hubungan antara motivasi intrinsik dan komitmen normatif sangat terbatas. Nilai atau kewajiban sosial yang membuat kepala sekolah bekerja bukanlah kebutuhan atau tujuan pribadi, tetapi kebutuhan pribadi dapat membentuk nilai sosial.

\section{Kepribadian Berpengaruh Langsung Positif terhadap Motivasi Kerja}

Hasil pengujian hipotesis diperoleh nillai koefisien jalur (p21) sebesar 0,366 yang artinya tolak $\mathrm{H}_{0}$ terima $\mathrm{H}_{1}$ hal ini membuktikan bahwa terdapat pengaruh langsung positif Kepribadian terhadap Motivasi Kerja kepala sekolah. Hasil analisis jalur antara variabel kepribadian dengan variabel motivasi kerja memberikan pengertian bahwa pengaruh kepribadian terhadap motivasi kerja adalah positif, yang dapat diartikan semakin baik kepribadian maka motivasi kerja kepala sekolah akan semakin tinggi, begitu juga sebaliknya semakin rendah Kepribadian akan di ikuti rendahnya komitmen normatif kepala sekolah.

Hasil penelitian ini mendukung hasil penelitian sebelumnya yang telah dilakukan oleh Nuckcheddy (2018) yang secara empiris telah membuktikan pengaruh besar kepribadian para pegawai terhadap motivasi mereka bekerja. Dimensi kepribadian yang terbukti memberikan pengaruh besar tersebut adalah kestabilan emosi dan keterbukaan. Selain itu, penelitian Yahaya, et.al (2012) juga menyoroti dimensi model lima besar kepribadian menunjukkan pengeruh yang tinggi terhadap motivasi dan komitmen organisasi yang pada akhirnya akan mempengaruhi kepuasan kerja. Sedangkan Griffin, et.al (2017) mengemukakan bahwa, "We noted earlier that individual differences play a key role in motivation. Simply put, different things motivate different people. As we explored in detail in 
our last two chapters, people have different abilities, needs, personalities, values, and self concept."

Dalam pernyataan di atas menjelaskan bahwa kepribadian seseorang memainkan peran kunci dalam motivasi kerja. Dalam penelitian ini secara terperinci dijelaskan bahwa setiap kepala sekolah memiliki kemampuan, kebutuhan, kepribadian, nilai, dan konsep diri yang berbeda.

\section{SIMPULAN}

Simpulan dalam penelitian ini adalah sebagai berikut: 1) terdapat pengaruh langsung positif yang signifikan kepribadian terhadap komitmen normatif, yang dapat diartikan semakin baik kepribadian maka komitmen normatif kepala sekolah akan meningkat, begitu juga sebaliknya semakin rendah kepribadian akan di ikuti rendahnya komitmen normatif kepala sekolah, 2) terdapat pengaruh langsung positif yang signifikan motivasi kerja terhadap komitmen normatif yang dapat diartikan tingkat motivasi kerja yang tinggi akan meningkatkan komitmen normatif kepala sekolah, begitu juga sebaliknya semakin rendah tingkat motivasi kerja akan di ikuti rendahnya komitmen normatif kepala sekolah, 3) terdapat pengaruh langsung positif yang signifikan kepribadian terhadap motivasi kerja yang dapat diartikan semakin baik kepribadian maka motivasi kerja kepala sekolah akan semakin tinggi, begitu juga sebaliknya semakin rendah Kepribadian akan di ikuti rendahnya komitmen normatif kepala sekolah.

\section{DAFTAR PUSTAKA}

Abdullah, I., Omar, R., \& Rashid, Y. (2013). Effect of personality on organizational commitment and employees' performance: Empirical evidence from banking sector of Pakistan. Middle-East Journal of Scientific Research, 18(6), 759-766. https://doi.org/10.5829/idosi.mejsr.2013.18.6.1685.

Colquitt, M. J., Lepine, J. A., \& Wesson, J. A. (2009). Organizational behavio: Essentials for improving performance and commitment. New York: McGraw-Hill Education, Inc.

Elleman, L. G., Condon, D. M., Russin, S. E., \& Revelle, W. (2018). The personality of U.S. sates: Stability from 1999 to 2015. Journal of Research in Personality, 72, 64-72.

Farrukh, M., Ying, C. W., \& Mansori, S. (2017). Organizational commitment: an empirical analysis of personality traits. Journal of Work-Applied Management, 9(1), 18-34. https://doi.org/10.1108/jwam-12-2016-0026.

Gibson, J. L., Ivancevich, J. M., Donnelly Jr, J. H., \& Konopaske, R. (2009). Organizations: Behavior, structure, processes. New York: McGraw-Hill Companies, Inc.

Griffin, R. W., Phillips, J. M., \& Gully, S. M. (2017). Organizational behavior: Managing people and organizations (12th ed.). Cengage Learning. 
Huang, Y. D. (2015). Impact of intrinsic motivation on organizational commitment: Empirical evidences from China. International Business and Management, 11(3), 31-44. https://doi.org/10.3968/7723

Khiavi, F. F., Dashti, R., \& Mokhtari, S. (2016). Association between organizational commitment and personality traits of faculty members of Ahvaz Jundishapur University of Medical Sciences. Electronic Physician, 8(3), 2129-2135. https://doi.org/http://dx.doi.org/10.19082/2129.

Kondalkar, V. G. (2007). Organizational behavior: An evidence-based approach. New Delhi: New Age International (P) Ltd., Publishers.

Kumar, N. (2012). Relationship of personal \& organizational values with organizational commitment. The Indian Journal of Industrial Relations, 48(2), 306-314.

Leephaijaroen, S. (2016). Effects of the big-five personality traits and organizational commitments on organizational citizenship behavior of support staff at Ubon Ratchathani Rajabhat University. Kasetsart Journal of Social Sciences, 37, 103-111. https://doi.org/https://doi.org/10.1016/j.kjss.2015.03.002.

Meyer, J. P., Stanley, D. J., Herscovitch, L., \& Topolnytsky, L. (2002). Affective, continuance, and normative commitment to the organization: A metaanalysis of antecedents, correlates, and consequences. Journal of Vocational Behavior, 61, 20-52.

Nelson, D. L., \& Cooper, C. L. (2007). Positive organizational behavior. Sage Publications, Inc.

Novian, Z., Akbar, M., \& Mukhtar, M. (2019). The effect of organizational structure, personality and work motivation on teacher organization commitments on International Islamic Education Council Foundation in Jakarta and Bekasi. Journal of Science and Science Education, 3(1), 19-31.

Nuckcheddy, A. (2018). The effect of personality on motivation and organisational behaviour. Psychology and Behavioral Science International Journal, 9(2), 001-005. https://doi.org/10.19080/pbsij.2018.09.555760

Oladiipo, S. A., Afolabi, S. O., Laosebikan, J. O., \& Nwachukwu, D. B. (2019). Impacts of Intrinsic Motivational Tools on Job Commitment of Employees in Selected Private University in South Western Nigeria. International Journal of Research and Scientific Innovation (IJRSI), VI(X), 180-193.

Rahmawati, Y., Abiddin, N. Z., \& Ro'is, I. (2015). Relationship between motivation and organizational commitment among scout volunteers in East Kalimantan. Journal of Social Science Studies, 2(1), 51-63. https://doi.org/10.5296/jsss.v2i1.6151

Selma, A. (2011). Job motivation and organizational commitment among the health professionals: A questionnaire survey. African Journal of Business Management, 5(21), 8601-8609. https://doi.org/10.5897/ajbm11.1086

Sinani, J. (2016). Motivational factors and organisational commitment of the educational institution's employee. Journal of Educational and Social Research, 6(1), 89-93. https://doi.org/10.5901/jesr.2016.v6n1p89

Supramono, S., Hardhienata, S., \& Sunaryo, W. (2015). The effect of organizational culture, personality, work moti- vation to teachers ' organizational commitment. International Journal of Managerial Studies and Research (IJMSR), 3(6), 165-170. 
Tella, A., Ayeni, C. O., \& Popoola, S. O. (2007). Work motivation, job satisfaction, and organisational commitment of library personnel in academic and research libraries in Oyo State, Nigeria. Library Philosophy and Practice 2007, (April), 1-16.

Yahaya, A., Yahaya, N., Bon, A. T., Ismail, S., \& Mohamed Noor, N. (2012). The relationship between big five personality with work motivation, competitiveness and job satisfaction. Elixir Psychology, 44, 7454-7461. 